\title{
Türkçe Öğretmeni Adaylarının Okuma Motivasyonlarının Çeşitli Değişkenler Açısından İncelenmesi
}

DOI: 10.26466/opus.588759

\author{
Nurullah Șahin* \\ * Dr. Öğr. Üyesi, Ağrı İbrahim Çeçen Üniversitesi, Eğitim Fakültesi Ağrı / Türkiye \\ E-Posta: nsahin.86@gmail.com \\ ORCID:0000-0002-3462-0369
}

\section{Öz}

Bu araştırmanın amacl; Türkçe öğretmeni adaylarının okuma motivasyonlarını çeşitli değ işkenler açısından incelemektir. Nicel araştırma yaklaşımının benimsendiği çalışmada tarama modeli kullanılmıştır. Araştırmanin çalışma grubunu 2018-2019 eğitim öğretim yılı güz döneminde; A ̈̆̆r İbrahim Çeçen Üniversitesi Ĕ̆itim Fakültesi Türkçe Ĕ̆itimi Ana Bilim Dalında öğrenim gören toplam 219 öğrenci oluşturmaktadır. Araştırmada veri toplama aracı olarak Schutte ve Malouff (2007) tarafindan geliştirilen ve Yildız vd. (2013) tarafindan Türkçeye uyarlanan "Yetişkin Okuma Motivasyonu Ölçeği" kullanılmıştır. Araştırmadan elde edilen tüm veriler, normal dağılım gösterdiği için veri analizinde parametrik testlerden faydalanılmıştır. Çalışmada; Türkçe öğretmeni adaylarının okuma motivasyonlarını, "Benlik" alt boyutunda cinsiyet, evde kütüphane I kitaplik bulunup bulunmaması, yılda okunan kitap saylsı ve evde kitap okuyan birinin olup olmaması faktörlerine göre; "Yeterlilik" alt boyutunda aile gelir düzeyi ve yılda okunan kitap sayısı faktörlerine göre; "Tanınma" alt boyutunda simıf ve yılda okunan kitap sayısı faktörlerine göre; "Diğer" alt boyutunda ise yılda okunan kitap sayısı ve evde kitap okuyan birinin olup olmaması faktörlerine göre anlamlı bir şekilde farklılaştığı görülmüştür.

Anahtar Kelimeler: Okuma, motivasyon, Türkçe öğretmeni adaylar 


\title{
Examination of The Reading Motivations of Turkish Teacher Candidates in Terms of Various Variables
}

\begin{abstract}
This study aims to examine the reading motivations of Turkish teacher candidates in terms of various variables. The study, in which a quantitative research approach was adopted, was conducted with the screening model. The study group consists of 219 students studying at the Turkish Education Department of the Faculty of Education of A ̆ğ İbrahim Çeçen University in the fall semester of the 2018-2019 academic year. "The Adult Reading Motivation Scale," developed by Schutte and Malouff (2007) and translated into Turkish by Yaldiz et al. (2013), was used in the study as the data collection tool. As all data obtained from the study were distributed normally, parametric tests were used in data analysis. It was seen in the study that the reading motivation of the teachers differed significantly according to the factors of gender, whether there was a library I bookcase at home, the number of books read per year, and whether there was someone reading book at home under the sub-dimension "Self"; according to the factors of family's income level and the number of books read per year under the sub-dimension "Competence"; according to the factors of grade and the number of books read per year under the sub-dimension of "Recognition"; and according to the factors of the number of books read per year and whether there was someone reading book at home under the sub-dimension "Other".
\end{abstract}

Keywords: Reading, motivation, Turkish teacher candidates. 


\section{Giriş}

İçinde yaşadığımız çağın bilgi çağı olması sebebiyle öğrenme, insan hayatının her anına yayılmış durumdadır. Çağdaş insanın yaşamın her anında var olabilmesi için, okullarda öğretilen bilgiler tek başına yetersiz kalmaktadır. Bu nedenle öğrenme, okulların dışına taşmış ve günümüzde doğumdan ölüme kadar geçen süreçte sürekli olarak gerçekleşebilen bir eylem hâline dönüşmüştür.

Bilgiye ulaşmanın ve öğrenmeyi gerçekleştirmenin önemli yollarından biri de okumadır. "Yazıya geçirilmiş bir metne bakarak bunu sessizce çözümleyip anlamak veya aynı zamanda seslere çevirmek" (TDK, 2009, s.1494) şeklinde tanımlanan okuma, dilin anlama boyutunu oluşturan iki temel beceriden birisidir. Yani okuma, basit bir şekilde kâğıda basılı harfleri seslendirmekten ibaret olan bir süreç değil, içerisinde kompleks zihinsel süreçleri de barındıran karmaşık bir eylemdir. Başarılı bir okumadan kasit, okunan metindeki anlamı ve mesajları tam olarak kavramak ve özümsemektir.

Okuma becerisi, okullarda eğitim yoluyla kazanılan bir beceridir ve okuma eğitimi son derece önem arz eden bir uğraştır. Okuma eğitimindeki amaç, çocukların yan yana yazılmış harfleri seslendirebilmeleri ile sınırlı değildir. Okunan metnin anlam derinliklerine inebilmek ve en önemlisi çocuklarda okuma sevgisi oluşturabilmek de okuma eğitiminin birincil amaçlarındandır. Çünkü okuma sevgisine sahip olan bireyler ancak hayatlarının her döneminde okumayı ve öğrenmeyi ön plana çıkarırlar ve okumayı bir ihtiyaç olarak görürler. Yani kaliteli ve bilinçli bir toplum oluşturabilmenin önemli ön koşullarından biri, okuma sevgisine sahip bireyler yetiştirmektir. Okuma sevgisi ise, küçük yaşlarda kazanılması çok daha kolay bir beceri olduğundan, okullardaki okuma eğitimi süreci bu bağlamda kritik bir önem arz etmektedir.

Okuma becerisi, bireylerin akademik hayatlarında da kritik öneme sahiptir. Hemen hemen her dersin temelinde okuma becerisi olduğunu düşünürsek, iyi bir okuma eğitiminin, bireylerin eğitim hayatları için de gerekli olduğunu söylemek yanlış olmaz. Eğitim sistemimizin önemli ölçüde okuma becerisi üzerine kurulu olması da, okuma becerisindeki başarının kritik önemini bir kez daha gözler önüne sermektedir. Ayrıca okuma, bireylerin kendilerini geliştirmesini ve ana dillerini etkili bir 
şekilde kullanabilmesine de yardım eder. Dili doğru ve etkili kullanabilme becerisi ise, akademik başarıyı beraberinde getirir (Kurudayığlu ve Çelik, 2013; MEB, 1995; Şahin, 2012 ve Ünalan, 2001).

Araştırmanın çalışma grubunu oluşturan Türkçe öğretmeni adayları açısından bakıldığında ise, Türkçe öğretmeni olmak isteyen ve bunun için eğitim alan bireylerin; mesleklerinin gerektirdiği donanıma sahip olmaları gerekmektedir (Ülper ve Bağcl, 2012). Bu bağlamda Türkçe öğretmenleri bilgi birikimin yanı sıra öz yeterlik bakımından yüksek özgüvene sahip olmalıdırlar (Korkut ve Babaoğlan, 2012). Okuma bunun için önemli yollardan birini teşkil etmektedir. Alanları itibariyle okuma ile iç içe olması beklenen Türkçe öğretmenleri; bu yolla kendilerini geliştirebilir ve öz yeterlik algılarını da yükseltebilirler. Nitekim Biçer ve Alan (2017), Türkçe öğretmeni adaylarının kitap okuma alışkanlıkları ile öz yeterlik algıları arasındaki ilişkiyi inceledikleri çalışmalarında, araştırmaya katılan Türkçe öğretmeni adaylarının kitap okuma alışkanlıkları arttıkça genel öz yeterlik puanlarının da arttığını ifade etmişlerdir. Çünkü okuma; bireylerde anlama, kavrama, sorgulama, düşünme, problem çözme, analiz etme, sentez yapma, değerlendirme, tasarlama ve ifade etme gibi üst düzey becerileri geliştirir (Güneş, 2007). Türkçe öğretmeni adayları da hem alanları gereği hem de öğretmenlik mesleğinin doğası gereği, kitap ve okuma sevgisine, okuma ile ilgili yüksek tutum ve motivasyona sahip olarak tüm bu becerileri kazanmalıdırlar. Türkçe öğretmenlerinin ve Türkçe öğretmeni adaylarının iyi birer okur olmaları, öğrencilerini iyi birer okuyucu olarak yetiştirmeleri bakımından da önem arz etmektedir. Okuyan ve araştıran bir nesil yetiştirebilmek adına, Türkçe öğretmenlerine önemli görevler düşmektedir. Bu nedenle, Türkçe öğretmenleri bu bilinçle okuma becerisi bağlamında kendilerini yetiştirmelidirler.

Okuma becerisi, içerisinde farklı değişkenler barındıran bir beceridir. Bundan dolayı da, okuma başarısını etkileyen birçok faktörden bahsetmek mümkündür. Fiziki, psikolojik, sosyal $v b$. birçok alanla ilişkili olan bu faktörlerin okullarda çocuklara okuma sevgisi ve becerisi kazandıracak şekilde düzenlenmesi gerekmektedir. Okuma başarısını doğrudan etkileyen faktörlerden biri de, motivasyondur.

Bir amacı gerçekleştirmek için desteklenme, teşvik görme ve davranışı sürekli kullanma yani sürdürme süreci olarak tanımlanan motivasyon (güdü); istekleri, arzuları, gereksinmeleri ve dürtüleri kapsayan genel bir 
kavram olarak tanımlanmaktadır (Pintrich ve Schunk, 1996 ve Sanc1, 2002). Yıldız (2010), motivasyonun bireyler için önemini, arabalar için yakıtın önemine benzetmektedir. Yani motivasyon, bireylerin işi sürdürebilmeleri için ihtiyaç duydukları yakıttır. “Öğrenci ve öğrenme açısından düşünüldüğünde motivasyon, öğrencinin öğrenmeye, anlamaya ve çalışmaya istek duymasını sağlayan etkidir" (Ürün Karahan, 2018, s. 113). Motivasyon; ilgili olduğu konuya, derslere veya alanlara göre farklılaşmaktadır. Motivasyon kavramının söz konusu olduğu derslerden biri de okumadır. Okuma motivasyonu, okuma eyleminin hedefine ulaşması için önemli bir faktör olarak karşımıza çıkmaktadır.

"Kitabı okumaya yönelik istek, merak, ilgi, tutum ve davranışın oluşabilmesi; kitap okumanın değerli bir eylem olarak görülmesi ve kitap okuma alışkanlığının devam edebilmesi için gerekli olan güç" (Katrancı, 2015, s.50) şeklinde tanımlanabilen okuma motivasyonunun, bireylerin / öğrencilerin okuma becerileri üzerinde önemli etkileri olduğunu ifade eden birçok çalışma (Akyol, 2005; Baker ve Wigfiled, 1999; Guthrie ve Wigfield, 2000; Paris, Wasik ve Turner, 1991; Turner, 1995; Wigfield ve Guthrie, 1997; Wigfield, Guthrie, Tonks ve Prencevich, 2004; Carnine, Silbert, Kame'enui, Tarver ve Jungjohann, 2006; Öztürk ve İleri Aydemir, 2013 vb.) literatürde yerini almıştır. Bu çalışmalar, okuma motivasyonu yüksek olan öğrencilerin okuma başarılarının da yüksek olduğunu ifade etmektedirler. Ayrıca yüksek okuma motivasyonu, okumaya yönelik olumlu duyguların ve davranışların gelişmesine de katkı sağladığı, bu araştırmalarda ifade edilen başka bir sonuç olarak karşımıza çıkmaktadır. Bu sebeplerden dolayı, okuma motivasyonunu artırıc tedbirler almak, bu doğrultuda plan ve projeler yapmak önemli görülmektedir.

\section{Araştırmanın Amacı}

Bu çalışmada, Türkçe öğretmeni adaylarının okuma motivasyonlarının çeşitli değişkenler açısından incelenmesi amaçlanmıştır. Bu doğrultuda, çalışmanın alt problemleri aşağıdaki şekilde belirlenmiştir:

1. Türkçe öğretmeni adaylarının okuma motivasyonları cinsiyetlerine göre anlamlı bir şekilde farklılaşmakta mıdır? 
2. Türkçe öğretmeni adaylarının okuma motivasyonları öğrenim görmekte oldukları sınıfa göre anlamlı bir şekilde farklılaşmakta mıdir?

3. Türkçe öğretmeni adaylarının okuma motivasyonları ailelerinin gelir düzeyine göre anlamlı bir şekilde farklılaşmakta mıdır?

4. Türkçe öğretmeni adaylarının okuma motivasyonları evlerinde kütüphane / kitaplık bulunup bulunmamasına göre anlamlı bir şekilde farklılaşmakta mıdır?

5. Türkçe öğretmeni adaylarının okuma motivasyonları bir yılda okudukları kitap sayısına göre anlamlı bir şekilde farklılaşmakta midir?

6. Türkçe öğretmeni adaylarının okuma motivasyonları evde kitap okuyan birinin olup olmamasına göre anlamlı bir şekilde farklılaşmakta midır?

\section{Yöntem}

\section{Araştırmanın Modeli}

Tarama modelinin kullanıldığı bu çalışmada, Türkçe öğretmeni adaylarının okuma motivasyonlarının çeşitli değişkenler açısından incelenmesi amaçlanmıştır. Tarama modeli geçmişte ya da günümüzde var olan bir durumu olduğu şekliyle betimlemeyi amaçlar (Karasar, 2008).

\section{Çalışma Grubu}

Araştırmanın çalışma grubunu, 2018-2019 eğitim öğretim yılı güz dönemi içerisinde, Ağrı İbrahim Çeçen Üniversitesi Eğitim Fakültesi Türkçe Eğitimi Ana Bilim Dalında öğrenim görmekte olan toplam 219 Türkçe öğretmeni adayı oluşturmaktadır. Araştırmanın çalışma grubunda yer alan öğretmen adaylarına ilişkin demografik bilgiler aşağıdaki tabloda dikkatlere sunulmuştur: 
Tablo 1. Çalışma grubuna ait demografik bilgiler

\begin{tabular}{|c|c|c|c|c|}
\hline & & $\mathbf{N}$ & $\%$ & Toplam \\
\hline \multirow[t]{2}{*}{ Cinsiyet } & Kadın & 122 & 55,7 & \multirow[t]{2}{*}{$219(\% 100)$} \\
\hline & Erkek & 97 & 44,3 & \\
\hline \multirow[t]{4}{*}{ Sinif } & 1. Sinif & 44 & 20,1 & \multirow{4}{*}{$219(\% 100)$} \\
\hline & 2. Sinif & 67 & 30,6 & \\
\hline & 3. Sinif & 54 & 24,7 & \\
\hline & 4. Sinif & 54 & 24,7 & \\
\hline \multirow[t]{4}{*}{ Aile Gelir Düzeyi } & $1-2000 \mathrm{TL}$ & 99 & 45,2 & \multirow{4}{*}{$219(\% 100)$} \\
\hline & $2001-4000 \mathrm{TL}$ & 91 & 41,6 & \\
\hline & $4001-6000 \mathrm{TL}$ & 19 & 8,7 & \\
\hline & 6000 Üzeri & 10 & 4,6 & \\
\hline \multirow{2}{*}{$\begin{array}{l}\text { Evdeki Kütüphane / } \\
\text { Kitaplık Durumu }\end{array}$} & Var & 126 & 57,5 & \multirow[t]{2}{*}{$219(\% 100)$} \\
\hline & Yok & 93 & 42,5 & \\
\hline \multirow{5}{*}{$\begin{array}{l}\text { Yılda Okunan Kitap } \\
\text { Sayıs1 }\end{array}$} & Hiç & 5 & 2,3 & \multirow{5}{*}{$219(\% 100)$} \\
\hline & 1-3 Adet & 35 & 16 & \\
\hline & 4-7 Adet & 71 & 32,4 & \\
\hline & 8-10 Adet & 48 & 21,9 & \\
\hline & 10 Üzeri & 60 & 27,4 & \\
\hline \multirow{2}{*}{$\begin{array}{l}\text { Evde Kitap Okuyan } \\
\text { Biri Olup Olmaması } \\
\text { Durumu }\end{array}$} & Var & 197 & 90 & \multirow[t]{2}{*}{$219(\% 100)$} \\
\hline & Yok & 22 & 10 & \\
\hline
\end{tabular}

\section{Verileri Toplama Araçları}

Kişisel Bilgi Formu: Araştırmacı tarafından hazırlanan bu formda, öğrencilerin cinsiyet, sınıf, aile gelir düzeyi, evde kütüphane / kitaplık bulunup bulunmadığı, yılda okudukları kitap sayısı ve evde kitap okuyan birinin olup olmadığını öğrenmeye yönelik sorular yer almaktadır.

Yetişkin Okuma Motivasyonu Ölçeği: Araştırmada kullanılan diğer bir veri toplama aracı ise, Yıldız vd. (2013) tarafından Türkçeye uyarlanan "Yetişkin Okuma Motivasyonu Ölçeği"dir. Schutte ve Malouff (2007) tarafından geliştirilen ölçeğin aslı, 4 faktör ve 21 maddeden oluşmaktadır. Ölçeğin faktörlerine bakıldığında;

- Benlik faktörü: Okuyucu olmanın önemine,

- Yeterlilik faktörü: Yeterli bir okuyucu olmaya,

- Tanınma faktörü: Okuma performansının diğerleri tarafından bilinmesine ve iyi bir okuyucu olarak kabul görmeye, 
- Diğer faktörü: Okumayı diğer alanlarda başarılı olmak için kullanmaya yönelik eğilimleri ifade etmektedir.

Yıldız vd. (2013), tarafından Türkçeye uyarlanan ölçek ise, 19 madde ve 4 alt boyuttan oluşmaktadır. Öncelikle ölçek Türkçeye çevrilmiş ve alanında uzman kişilerden alınan görüşler neticesinde gerekli düzenlemeler yapılarak ölçeğin dilsel eşdeğerliği sağlanmıştır. Ardından araştırmacılar tarafından doğrulayıcı ve açımlayıcı faktör analizleri yapılmış; ölçeğin alt boyutlarına ve geneline yönelik iç tutarlılık katsayıları hesaplanmıştır. Ölçeğin iç tutarlılık katsayıları "Benlik" alt boyutunda .82, "Yeterlilik" alt boyutunda .60, "Tanınma" alt boyutunda .78, "Diğer" alt boyutunda .72 ve ölçeğin genelinde ise .86 olarak hesaplanmıştır. Bu sonuçlardan yola çıkan Yıldız vd. (2013), elde ettikleri ölçeğin, yetişkinlerin okuma motivasyonlarını ölçmesi bakımından geçerli ve güvenilir bir ölçme aracı olduğunu ifade etmişlerdir.

\section{Verilerin Analizi}

Araştırmanın tüm verileri SPSS 25 istatistik programı kullanılarak analiz edilmiştir. Verilerin analizine geçilmeden önce araştırmaya katılan Türkçe öğretmeni adaylarının motivasyon ölçeğinden almış oldukları puanların normal dağılım gösterip göstermediğini tespit etmek için çarpıklık ve basıklık değerleri incelenmiştir. Elde edilen sonuçlar, verilerin normal dağıldığını gösterdiği için yapılan analizlerde parametrik testler kullanılmıştır. Bu bağlamda, Türkçe öğretmeni adaylarının okuma motivasyonlarının "cinsiyet", "evde kütüphane / kitaplık bulunup bulunmaması" ve "evde kitap okuyan birinin olup olmaması" değişkenlerine göre anlamlı bir farklılık gösterip göstermediği bağımsız t-testi analizi ile; "sınıf", "aile gelir düzeyi" ve "yılda okunan kitap sayısı" değişkenlerine göre anlamlı bir farklılık gösterip göstermediği ise, tek faktörlü varyans analizi ile incelenmiştir. Tek faktörlü varyans analizi neticesinde anlamlı farkın hangi gruplar lehine olduğunu tespit etmede, "LSD" testinden faydalanılmıştır. Elde edilen sonuçların, araştırmanın alt amaçlarına uygun olacak şekilde tablolar kullanılarak gösterildiği çalışmada, verilerin anlamlılığı $\mathrm{p}<.05$ düzeyinde sınanmıştır. 


\section{Bulgular}

\section{Araştırma İçin Toplanan Verilerin Normallik Testi Sonuçları}

Araştırmada, toplanan verilerin normal dağılım gösterip göstermediklerini tespit etmek için çarpıklık ve basıklık değerlerine bakılmıştır. Elde edilen sonuçlar aşağıdaki tabloda gösterilmiştir.

Tablo 2. Araştırma için toplanan verilerin çarpıklık ve basıklık değerleri

\begin{tabular}{lllll}
\hline & $\mathbf{N}$ & \multicolumn{2}{c}{ Skewness } & Kurtosis \\
\cline { 2 - 3 } & Valid & Missing & & \\
\hline Benlik Alt Boyutu & 219 & 0 &,- 103 &,- 296 \\
\hline Yeterlilik Alt Boyutu & 219 & 0 &,- 079 & -128 \\
\hline Tanınma Alt Boyutu & 219 & 0 &,- 248 &,- 535 \\
\hline Diğer Alt Boyutu & 219 & 0 &,- 285 &,- 447 \\
\hline
\end{tabular}

Çarpıklık ve basıklık değerlerinin bulundukları aralıklar, verilerin normal dağılıp dağılmadığını göstermesi bakımından önemlidir. George ve Mallery'e (2010) göre; çarpıklık ve basıklık değerlerinin +2 ile -2 arasında olması verilerin normal dağılımı için yeterli görülürken, Tabachnick ve Fidell'a (2013) göre ise, normal dağılımdan bahsedebilmek için bu değerlerin $+1,5$ ile $-1,5$ arasında olması gerekmektedir. Bu bağlamda görüş belirten Hair $v d$. (2013) ise, çarpıklık ve basıklık değerlerinin +1 ile -1 arasında yer alması durumunda normal dağılımın kabul edilebileceğini ifade etmişlerdir. Tablo 2 incelendiğinde araştırma için toplanan verilerin ölçeğin tüm alt boyutlarındaki çarpıklık ve basıklık değerlerinin +1 ile -1 arasinda olduğu görülmektedir. Bu durum yukarıda verilen tüm kaynaklara göre, araştırmanın verilerinin normal dağıldığını göstermektedir. Bu sebeple de veriler analiz edilirken parametrik testlerden faydalanılmıştır.

\section{Türkçe Öğretmeni Adaylarının Okuma Motivasyonlarının Cinsiyet Değişkenine Göre İncelenmesi}

Bu bölümde; Türkçe öğretmeni adaylarının okuma motivasyonlarının cinsiyete göre anlamlı bir şekilde farklılaşıp farklılaşmadığı araştırılmıştır. 
Bunun için Türkçe öğretmeni adaylarının motivasyon ölçeğine vermiş oldukları cevaplar bağımsız örneklem t- testi ile analiz edilmiştir. İlgili analizden elde edilen sonuçlar Tablo 3'te gösterilmiştir.

Tablo 3. Türkçe öğretmeni adaylarının okuma motivasyonlarının cinsiyete göre farklılaşıp farklılaşmadı̆̆ına ilişkin analiz sonuçları

\begin{tabular}{|c|c|c|c|c|c|c|}
\hline & & $\mathbf{N}$ & $x$ & S.s & $t$ & $p$ \\
\hline \multirow{2}{*}{$\begin{array}{l}\text { Benlik Alt } \\
\text { Boyutu }\end{array}$} & Kadın & 122 & 3,99 & ,484 & \multirow{2}{*}{ 713 } & \multirow[t]{2}{*}{,006 } \\
\hline & Erkek & 97 & 3,80 & ,507 & & \\
\hline \multirow{2}{*}{$\begin{array}{l}\text { Yeterlilik } \\
\text { Alt Boyutu }\end{array}$} & Kadın & 122 & 3,55 & 623 & \multirow[t]{2}{*}{ 686 } & \multirow[t]{2}{*}{837} \\
\hline & Erkek & 97 & 3,57 & 629 & & \\
\hline \multirow{2}{*}{$\begin{array}{l}\text { Taninma Alt } \\
\text { Boyutu }\end{array}$} & Kadın & 122 & 3,34 & ,972 & \multirow[t]{2}{*}{ 681 } & \multirow[t]{2}{*}{ 706 } \\
\hline & Erkek & 97 & 3,29 & ,942 & & \\
\hline \multirow{2}{*}{$\begin{array}{l}\text { Diğer Alt } \\
\text { Boyutu }\end{array}$} & Kadın & 122 & 3,78 & 633 & \multirow[t]{2}{*}{ 198 } & \multirow[t]{2}{*}{ 137 } \\
\hline & Erkek & 97 & 3,64 & ,710 & & \\
\hline
\end{tabular}

Tablo 3 incelendiğinde; Türkçe öğretmeni adaylarının okuma motivasyonu düzeylerinin cinsiyetlerine göre anlamlı olarak farklılaşıp farklılaşmadığını belirlemek için yapılan bağımsız örneklemler t-testi sonucunda ortalamalar arasındaki farkın "Benlik" alt boyutunda kadınlar

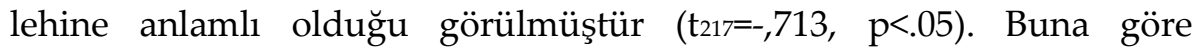
cinsiyetin, okumayı benliklerinin bir parçası olarak görme noktasında, Türkçe öğretmeni adaylarının okuma motivasyonlarını etkileyen bir faktör olduğu söylenebilir. Motivasyon ölçeğinin diğer alt boyutlarında ise, kadın ve erkeklerin ortalamaları arasındaki farkın anlamlı olmadığı görülmüştür. Buna göre cinsiyetin, "Yeterlilik" (t217=-,686, p>.05), “Tanınma" ( $\mathrm{t}_{217}=-, 681, \mathrm{p}>$.05) ve "Diğer" (t217=-,198, p>.05) alt boyutlarında, Türkçe öğretmeni adaylarının okuma motivasyonu düzeylerini etkileyen bir faktör olmadığı söylenebilir.

Türkçe Öğretmeni Adaylarının Okuma Motivasyonlarının Öğrenim Görmekte Olduklan Sınf Değişkenine Göre İncelenmesi

Bu bölümde; Türkçe öğretmeni adaylarının okuma motivasyonlarının öğrenim görmekte oldukları sınıf değişkenine göre anlamlı bir şekilde farklılaşıp farklılaşmadığı araştırılmıştır. Bunun için Türkçe öğretmeni aday- 
larının motivasyon ölçeğine vermiş oldukları cevaplar üzerinde tek faktörlü varyans analizi uygulanmıştır. İlgili analizden elde edilen sonuçlar Tablo 4'te gösterilmiştir.

Tablo 4. Türkçe öğretmeni adaylarının okuma motivasyonlarının öğrenim görmekte oldukları sınıfa göre farklılaşıp farklılaşmadığına ilişkin analiz sonuçları

\begin{tabular}{|c|c|c|c|c|c|c|c|c|}
\hline & Sinif & $\mathbf{N}$ & $x$ & S.s & sd & F & $p$ & $\begin{array}{l}\text { Anlamlı } \\
\text { Fark }\end{array}$ \\
\hline \multirow{4}{*}{$\begin{array}{l}\text { Benlik } \\
\text { Alt Boyutu }\end{array}$} & 1. Sinıf & 44 & 3,86 & ,552 & \multirow[t]{4}{*}{$3 / 215$} & \multirow[t]{4}{*}{,373 } & \multirow[t]{4}{*}{,773 } & \multirow[t]{4}{*}{---} \\
\hline & 2. Sinif & 67 & 3,95 & ,481 & & & & \\
\hline & 3. Sinif & 54 & 3,91 & ,533 & & & & \\
\hline & 4. Sinif & 54 & 3,88 & ,461 & & & & \\
\hline \multirow{4}{*}{$\begin{array}{l}\text { Yeterlilik } \\
\text { Alt Boyutu }\end{array}$} & 1. Sinif & 44 & 3,56 & ,704 & \multirow[t]{4}{*}{$3 / 215$} & \multirow[t]{4}{*}{ 110 } & \multirow[t]{4}{*}{,954 } & \multirow[t]{4}{*}{---} \\
\hline & 2. Sinif & 67 & 3,58 & ,547 & & & & \\
\hline & 3. Sinif & 54 & 3,52 & ,655 & & & & \\
\hline & 4. Sinif & 54 & 3,56 & ,629 & & & & \\
\hline \multirow{4}{*}{$\begin{array}{l}\text { Taninma } \\
\text { Alt Boyutu }\end{array}$} & 1. Sinıf & 44 & 3,24 & 816 & \multirow[t]{4}{*}{$3 / 215$} & \multirow[t]{4}{*}{3,460} & \multirow[t]{4}{*}{,017 } & $2-1$ \\
\hline & 2. Sinif & 67 & 3,62 & ,968 & & & & $2-3$ \\
\hline & 3. Sinif & 54 & 3,25 & 1,01 & & & & $2-4$ \\
\hline & 4. Sinif & 54 & 3,09 & ,928 & & & & \\
\hline \multirow{4}{*}{$\begin{array}{l}\text { Diğer } \\
\text { Alt Boyutu }\end{array}$} & 1. Sinif & 44 & 3,75 & ,598 & \multirow[t]{4}{*}{$3 / 215$} & \multirow[t]{4}{*}{ 376 } & \multirow[t]{4}{*}{ 771 } & \multirow[t]{4}{*}{---} \\
\hline & 2. Sinif & 67 & 3,65 & ,734 & & & & \\
\hline & 3. Sinif & 54 & 3,77 & 699 & & & & \\
\hline & 4. Sinıf & 54 & 3,71 & 623 & & & & \\
\hline
\end{tabular}

Türkçe öğretmeni adaylarının okuma motivasyonu düzeylerinin öğrenim görmekte oldukları sınıf düzeyine göre anlamlı olarak farklılaşıp farklılaşmadığını belirlemek için yapılan tek faktörlü ANOVA sonucunda aradaki farkın "Tanınma" alt boyutunda anlamlı olduğu bulunmuştur $\left(\mathrm{F}_{215}=3,460, \mathrm{p}<.05\right)$. Farkın hangi ortalamalar arasında olduğunu belirlemek için çoklu karşılaştırma testlerinden "LSD" testi uygulanmış ve 2. sınıfta öğrenim görmekte olan Türkçe öğretmeni adaylarının "Tanınma” alt boyutunda okuma motivasyonlarının, diğer sınıf düzeylerinde öğrenim görmekte olanlara göre anlamlı düzeyde arttığı bulunmuştur. 1. sinıfta öğrenim görmekte olan öğrencilerin aritmetik ortalamasının $X=3,24$, 2. sinıfta öğrenim görmekte olanların $X=3,62$, 3. sinıfta öğrenim görmekte olanların $X=3,25$ ve 4 . sinıfta öğrenim görmekte olanların ise $X=3,09$ olduğu görülmektedir. Buna göre; öğrenim görülen sınıf düzeyi, 
"Tanınma" alt boyutunda, Türkçe öğretmeni adaylarının okuma motivasyonlarını etkileyen bir faktör olarak değerlendirilebilir. Ölçeğin "Benlik" ( $\left.F_{215}=, 373, p>.05\right)$, "Yeterlilik" ( $\left.F_{215}=, 110, p>.05\right)$ ve “Diğer" $\left(F_{215}=, 376\right.$, $\mathrm{p}>.05$ ) alt boyutlarında ise aradaki farkın anlamlı olmadığı görülmektedir. Buna göre öğrenim görülen sınıf düzeyinin, "Benlik", "Yeterlilik" ve "Diğer" alt boyutlarında, Türkçe öğretmeni adaylarının okuma motivasyonları üzerinde anlamlı bir etkiye sahip olmadığı söylenebilir.

\section{Türkçe Öğretmeni Adaylarının Okuma Motivasyonlarının Aile Gelir Dü- zeyleri Değişkenine Göre İncelenmesi}

Bu bölümde; Türkçe öğretmeni adaylarının okuma motivasyonlarının aile gelir düzeyleri değişkenine göre anlamlı bir şekilde farklılaşıp farklılaşmadığı araştırılmıştır. Bunun için Türkçe öğretmeni adaylarının motivasyon ölçeğine vermiş oldukları cevaplar üzerinde tek faktörlü varyans analizi uygulanmıştır. İlgili analizden elde edilen sonuçlar Tablo 5 'te gösterilmiştir.

Tabloya göre; Türkçe öğretmeni adaylarının okuma motivasyonu düzeylerinin aylık aile gelir düzeyine göre anlamlı olarak farklılaşıp farklılaşmadığını belirlemek için yapılan tek faktörlü ANOVA sonucunda aradaki farkın "Yeterlilik" alt boyutunda anlamlı olduğu bulunmuştur $\left(\mathrm{F}_{215}=3,086, \mathrm{p}<.05\right)$. Farkın hangi ortalamalar arasında olduğunu belirlemek için çoklu karşılaştırma testlerinden "LSD" testi uygulanmış ve aylık aile gelir düzeyi "2001-4000 TL" bandında olan öğrencilerin okuma motivasyonu düzeylerinin, "1-2000 TL" ve "6000 TL Üzeri” gelir gruplarında yer alan öğrencilere göre anlamlı düzeyde azaldığı bulunmuştur. Aile gelir düzeyi "1-2000 TL" arasında yer alan öğrencilerin aritmetik ortalama$\operatorname{sinın} X=3,67$, “2001-4000 TL" arasında olanların $X=3,42$, ve "6000 TL üzeri" olanların ise $X=3,87$ olduğu görülmektedir. Buna göre; aile gelir düzeyi, "Yeterlilik" alt boyutunda, Türkçe öğretmeni adaylarının okuma motivasyonlarını etkileyen bir faktör olarak değerlendirilebilir. Ölçeğin "Benlik" ( $\left.F_{215}=, 724, p>.05\right)$, “Tanınma" ( $\left.F_{215}=, 580, p>.05\right)$ ve “Diğer" ( $\left.F_{215}=, 532, p>.05\right)$ alt boyutlarında ise aradaki farkın anlamlı olmadığı görülmektedir. Buna göre aile gelir düzeyinin, "Benlik", "Tanınma" ve "Diğer" alt boyutlarında, Türkçe öğretmeni adaylarının okuma motivasyonları üzerinde anlamlı bir etkiye sahip olmadığı söylenebilir. 
Tablo 5. Türkçe öğretmeni adaylarını okuma motivasyonlarını aile gelir düzeylerine göre farklılaşıp farklılaşmadı̆̆ına ilişkin analiz sonuçları

\begin{tabular}{|c|c|c|c|c|c|c|c|c|}
\hline & Aile Gelir Düzeyi & $\mathbf{N}$ & $x$ & S.s & sd & F & p & $\begin{array}{l}\text { Anlaml } \\
\text { Fark }\end{array}$ \\
\hline \multirow{4}{*}{$\begin{array}{l}\text { Benlik } \\
\text { Alt } \\
\text { Boyutu }\end{array}$} & 1-2000 TL (A) & 99 & 3,94 & ,466 & \multirow[t]{4}{*}{$3 / 215$} & \multirow[t]{4}{*}{ 724 } & \multirow[t]{4}{*}{, 539} & \multirow[t]{4}{*}{--- } \\
\hline & 2001-4000 TL (B) & 91 & 3,85 & 488 & & & & \\
\hline & 4001-6000 TL (C) & 19 & 3,99 &, 549 & & & & \\
\hline & 6000 Üzeri TL (D) & 10 & 3,93 & ,834 & & & & \\
\hline \multirow{4}{*}{$\begin{array}{l}\text { Yeterli- } \\
\text { lik Alt } \\
\text { Boyutu }\end{array}$} & $1-2000$ TL (A) & 99 & 3,63 & ,616 & \multirow[t]{4}{*}{$3 / 215$} & \multirow[t]{4}{*}{3,086} & \multirow[t]{4}{*}{, 028 } & \multirow{4}{*}{$\begin{array}{l}\text { A-B } \\
\text { D-B }\end{array}$} \\
\hline & 2001-4000 TL (B) & 91 & 3,42 & ,586 & & & & \\
\hline & 4001-6000 TL (C) & 19 & 3,67 & ,634 & & & & \\
\hline & 6000 Üzeri TL (D) & 10 & 3,87 & 827 & & & & \\
\hline \multirow{4}{*}{$\begin{array}{l}\text { Tanınma } \\
\text { Alt } \\
\text { Boyutu }\end{array}$} & 1-2000 TL (A) & 99 & 3,41 & 967 & \multirow[t]{4}{*}{$3 / 215$} & \multirow[t]{4}{*}{ 656 } & \multirow[t]{4}{*}{, 580} & \multirow[t]{4}{*}{---} \\
\hline & 2001-4000 TL (B) & 91 & 3,22 & ,982 & & & & \\
\hline & 4001-6000 TL (C) & 19 & 3,34 & 800 & & & & \\
\hline & 6000 Üzeri TL (D) & 10 & 3,30 & ,935 & & & & \\
\hline \multirow{4}{*}{$\begin{array}{l}\text { Diğer Alt } \\
\text { Boyutu }\end{array}$} & 1-2000 TL (A) & 99 & 3,75 & 668 & \multirow[t]{4}{*}{$3 / 215$} & \multirow[t]{4}{*}{, 532} & \multirow[t]{4}{*}{,661 } & \multirow[t]{4}{*}{---} \\
\hline & 2001-4000 TL (B) & 91 & 3,66 & 659 & & & & \\
\hline & 4001-6000 TL (C) & 19 & 3,84 & 669 & & & & \\
\hline & 6000 Üzeri TL (D) & 10 & 3,63 & 840 & & & & \\
\hline
\end{tabular}

Türkçe Öğretmeni Adaylarının Okuma Motivasyonlarının Evde Kütüphane / Kitaplık Bulunup Bulunmaması Değişkenine Göre İncelenmesi

Bu bölümde; Türkçe öğretmeni adaylarının okuma motivasyonlarının evde kütüphane / kitaplık bulunup bulunmaması değişkenine göre anlamlı bir şekilde farklılaşıp farklılaşmadı̆̆ı araştırılmıştır. Bunun için Türkçe öğretmeni adaylarının motivasyon ölçeğine vermiş oldukları cevaplar bağımsız örneklem t- testi ile analiz edilmiştir. İlgili analizden elde edilen sonuçlar Tablo 6' da gösterilmiştir.

Tablo 6 incelendiğinde; Türkçe öğretmeni adaylarının okuma motivasyonu düzeylerinin evde kütüphane / kitaplık bulunup bulunmamasına göre anlamlı olarak farklılaşıp farklılaşmadığını belirlemek için yapılan bağımsız örneklemler t-testi sonucunda ortalamalar arasındaki farkın "Benlik" alt boyutunda, evinde kütüphane / kitaplık bulunan öğrenciler lehine anlamlı olduğu görülmüştür ( $\left.\mathrm{t}_{21}=2,042, \mathrm{p}<.05\right)$. 
Tablo 6. Türkçe öğretmeni adaylarının okuma motivasyonlarının evde kütüphane / kitaplık bulunup bulunmamasına göre farklılaşıp farklılaşmadığına ilişkin analiz sonuçlar

\begin{tabular}{|c|c|c|c|c|c|c|}
\hline & & $\mathbf{N}$ & $x$ & S.s & $\mathbf{t}$ & p \\
\hline \multirow[t]{2}{*}{ Benlik Alt Boyutu } & Var & 126 & 3,96 & ,506 & \multirow[t]{2}{*}{2,042} & \multirow[t]{2}{*}{,042 } \\
\hline & Yok & 93 & 3,82 & 488 & & \\
\hline \multirow[t]{2}{*}{ Yeterlilik Alt Boyutu } & Var & 126 & 3,61 & 619 & \multirow[t]{2}{*}{1,518} & \multirow[t]{2}{*}{130} \\
\hline & Yok & 93 & 3,48 & ,626 & & \\
\hline \multirow[t]{2}{*}{ Tanınma Alt Boyutu } & Var & 126 & 3,28 & ,900 & \multirow[t]{2}{*}{,- 668} & \multirow[t]{2}{*}{,505 } \\
\hline & Yok & 93 & 3,37 & 1,03 & & \\
\hline \multirow[t]{2}{*}{ Diğer Alt Boyutu } & Var & 126 & 3,75 & ,664 & \multirow[t]{2}{*}{,774 } & \multirow[t]{2}{*}{ 440, } \\
\hline & Yok & 93 & 3,67 & 680 & & \\
\hline
\end{tabular}

Buna göre; evlerinde kütüphane / kitaplık bulunan Türkçe öğretmeni adaylarının "Benlik" alt boyutunda, okuma motivasyonlarını, evlerinde kütüphane / kitaplık bulunmayanlara göre daha yüksek olduğu söylenebilir. Diğer alt boyutlarda ise, evlerinde kütüphane / kitaplık bulunan Türkçe öğretmeni adayları ile bulunmayanlar arasındaki farkın anlamlı olmadığı görülmüş̧ür. Buna göre evde kütüphane / kitaplık bulunup bu-

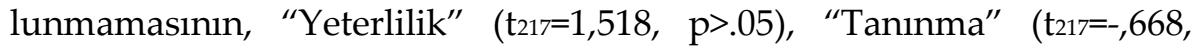
$\mathrm{p}>$.05) ve "Diğer" ( $\left.\mathrm{t}_{217}=, 774, \mathrm{p}>.05\right)$ alt boyutlarında, Türkçe öğretmeni adaylarının okuma motivasyonu düzeylerini etkileyen bir faktör olmadığı söylenebilir.

\section{Türkçe Öğretmeni Adaylarının Okuma Motivasyonlarının Yılda Okunan Kitap Sayısı Değişkenine Göre İncelenmesi}

Bu bölümde; Türkçe öğretmeni adaylarının okuma motivasyonlarının yılda okunan kitap sayısı değişkenine göre anlamlı bir şekilde farklılaşıp farklılaşmadığı araştırılmıştır. Bunun için Türkçe öğretmeni adaylarının motivasyon ölçeğine vermiş oldukları cevaplar üzerinde tek faktörlü varyans analizi uygulanmıştır. İlgili analizden elde edilen sonuçlar Tablo 7' de gösterilmiştir.

Tabloya göre; Türkçe öğretmeni adaylarının okuma motivasyonu düzeylerinin yılda okudukları kitap sayısına göre anlamlı olarak farklılaşıp farklılaşmadığını belirlemek için yapılan tek faktörlü ANOVA sonucunda aradaki farkın tüm "Benlik" alt boyutunda anlamlı olduğu bulunmuştur $\left(\mathrm{F}_{214}=14,686, \mathrm{p}<.05\right)$. 
Tablo 7. Türkçe öğretmeni adaylarının okuma motivasyonlarının yılda okunan kitap sayısına göre farklılaşıp farklılaşmadığına ilişkin analiz sonuçları

\begin{tabular}{|c|c|c|c|c|c|c|c|c|}
\hline & Kitap Sayısı & $\mathbf{N}$ & $x$ & S.s & sd & F & p & $\begin{array}{l}\text { Anlamlı } \\
\text { Fark }\end{array}$ \\
\hline \multirow{5}{*}{ 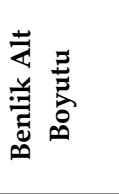 } & Hiç (A) & 5 & 3,07 & ,488 & \multirow[t]{5}{*}{$4 / 214$} & \multirow[t]{5}{*}{14,686} & \multirow[t]{5}{*}{,000 } & B-A / C-A \\
\hline & 1-3 Adet (B) & 35 & 3,61 & 460 & & & & D-A / E-A \\
\hline & 4-7 Adet (C) & 71 & 3,84 & ,448 & & & & C-B / D-B \\
\hline & 8-10 Adet (D) & 48 & 3,94 & ,469 & & & & D-C / E-B \\
\hline & 10 Üzeri (E) & 60 & 4,19 & ,424 & & & & E-C / E-D \\
\hline \multirow{5}{*}{ 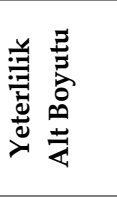 } & Hiç (A) & 5 & 3,40 & ,547 & \multirow[t]{5}{*}{$4 / 214$} & \multirow[t]{5}{*}{3,503} & \multirow[t]{5}{*}{,009 } & E-B \\
\hline & 1-3 Adet (B) & 35 & 3,38 & 651 & & & & $\mathrm{E}-\mathrm{C}$ \\
\hline & 4-7 Adet (C) & 71 & 3,43 & 690 & & & & \\
\hline & 8-10 Adet (D) & 48 & 3,62 & ,509 & & & & \\
\hline & 10 Üzeri (E) & 60 & 3,77 &, 563 & & & & \\
\hline \multirow{5}{*}{ 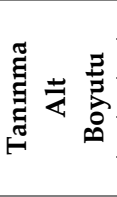 } & Hiç (A) & 5 & 2,80 & 1,04 & \multirow[t]{5}{*}{$4 / 214$} & \multirow[t]{5}{*}{2,444} & \multirow[t]{5}{*}{,048 } & B-A / B-C \\
\hline & 1-3 Adet (B) & 35 & 3,74 & 964 & & & & B-D / B-E \\
\hline & 4-7 Adet (C) & 71 & 3,31 & ,961 & & & & \\
\hline & 8-10 Adet (D) & 48 & 3,19 & ,960 & & & & \\
\hline & 10 Üzeri (E) & 60 & 3,23 & 891 & & & & \\
\hline \multirow{5}{*}{ 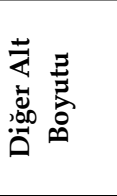 } & Hiç (A) & 5 & 2,99 & 847 & \multirow[t]{5}{*}{$4 / 214$} & \multirow[t]{5}{*}{2,740} & \multirow[t]{5}{*}{,030 } & C-A \\
\hline & 1-3 Adet (B) & 35 & 3,61 & ,745 & & & & D-A \\
\hline & 4-7 Adet (C) & 71 & 3,76 & ,665 & & & & E-A \\
\hline & 8-10 Adet (D) & 48 & 3,62 & 617 & & & & \\
\hline & 10 Üzeri (E) & 60 & 3,86 & 619 & & & & \\
\hline
\end{tabular}

Farkın hangi ortalamalar arasında olduğunu belirlemek için çoklu karşılaştırma testlerinden "LSD" testi uygulanmış ve yılda okunan kitap sayısı okuma motivasyonu arasında pozitif yönde bir ilişki bulunmuştur. Yani Türkçe öğretmeni adaylarının yılda okudukları kitap sayısı arttıkça, "Benlik" alt boyutunda, okuma motivasyonu düzeylerinin de arttığı görülmüştür. Yılda "Hiç" kitap okumayan öğretmen adaylarının aritmetik ortalamasinin $X=3,07$, "1-3 adet" arasinda okuyanların $X=3,61$, "4-7 adet" arasinda okuyanlarin $X=3,84$, "8-10 adet" arasinda okuyanlarin $X=3,94$ ve "10 üzeri" okuyanların ise $X=4,19$ olduğu görülmektedir. Buna göre; Türkçe öğretmeni adaylarının yıl içerisinde az sayıda kitap okumaları, düşük okuma motivasyonu yaşamalarını etkileyen bir faktör olarak değerlendirilebilir.

Türkçe öğretmeni adaylarının okuma motivasyonu düzeylerinin yılda okudukları kitap sayısına göre anlamlı olarak farklılaşıp farklılaşmadı̆̆ını belirlemek için yapılan tek faktörlü ANOVA sonucunda aradaki farkın 
tüm "Yeterlilik" alt boyutunda anlamlı olduğu bulunmuştur $\left(\mathrm{F}_{214}=3,503\right.$, $\mathrm{p}<.05)$. Farkın hangi ortalamalar arasında olduğunu belirlemek için çoklu karşılaştırma testlerinden "LSD" testi uygulanmış ve yılda "10 Üzeri" kitap okuyan öğretmen adaylarının "Yeterlilik" alt boyutundaki okuma motivasyonlarını, "1-3 adet" ve "4-7 adet" okuyan öğretmen adaylarına göre anlamlı bir şekilde arttığı bulunmuştur. Yılda "Hiç" kitap okumayan öğretmen adaylarının aritmetik ortalamasının $X=3,40$, "1-3 adet" arasında okuyanlarin $X=3,38$, "4-7 adet" arasinda okuyanlarin $X=3,43$, "8-10 adet" arasında okuyanların $X=3,62$ ve "10 üzeri" okuyanların ise $X=3,77$ olduğu görülmektedir. Buna göre yılda okunan kitap sayısı, "Yeterlilik" alt boyutunda, Türkçe öğretmeni adaylarının okuma motivasyonlarını etkileyen bir faktör olarak değerlendirilebilir.

Türkçe öğretmeni adaylarının okuma motivasyonu düzeylerinin yılda okudukları kitap sayısına göre anlamlı olarak farklılaşıp farklılaşmadığını belirlemek için yapılan tek faktörlü ANOVA sonucunda aradaki farkın tüm "Tanınma" alt boyutunda anlamlı olduğu bulunmuştur $\left(F_{214}=2,444\right.$, $\mathrm{p}<.05)$. Farkın hangi ortalamalar arasında olduğunu belirlemek için çoklu karşılaştırma testlerinden "LSD" testi uygulanmış ve yılda "1-3 adet" kitap okuyan öğretmen adaylarının "Yeterlilik" alt boyutundaki okuma motivasyonlarını, diğer aralıklarda yer alan öğretmen adaylarına göre anlamlı bir şekilde arttığı bulunmuştur. Yılda "Hiç" kitap okumayan öğretmen adaylarının aritmetik ortalamasinın $X=2,80$, "1-3 adet" arasında okuyanlarin $X=3,74$, " $4-7$ adet" arasinda okuyanlarin $X=3,31$, "8-10 adet" arasinda okuyanların $X=3,19$ ve "10 üzeri" okuyanların ise $X=3,23$ olduğu görülmektedir. Buna göre yılda okunan kitap sayısı, "Tanınma” alt boyutunda, Türkçe öğretmeni adaylarının okuma motivasyonlarını etkileyen bir faktör olarak değerlendirilebilir.

Türkçe öğretmeni adaylarının okuma motivasyonu düzeylerinin yılda okudukları kitap sayısına göre anlamlı olarak farklılaşıp farklılaşmadığını belirlemek için yapılan tek faktörlü ANOVA sonucunda aradaki farkın tüm "Diğer" alt boyutunda anlamlı olduğu bulunmuştur ( $F_{214}=2,740$, $\mathrm{p}<.05)$. Farkın hangi ortalamalar arasında olduğunu belirlemek için çoklu karşılaştırma testlerinden "LSD" testi uygulanmış ve yılda "Hiç" kitap okumayan öğretmen adaylarının "Yeterlilik" alt boyutundaki okuma motivasyonlarının; "4-7 adet", "8-10 adet" ve "10 üzeri" aralıklarında yer alan öğretmen adaylarına göre anlamlı bir şekilde azaldığı bulunmuştur. 
Yılda "Hiç" kitap okumayan öğretmen adaylarının aritmetik ortalamas1nin $X=2,99$, "1-3 adet" arasinda okuyanlarin $X=3,61$, "4-7 adet" arasinda okuyanların $X=3,76$, "8-10 adet" arasinda okuyanların $X=3,62$ ve "10 üzeri" okuyanların ise $X=3,86$ olduğu görülmektedir. Buna göre yılda okunan kitap sayısı, "Diğer" alt boyutunda, Türkçe öğretmeni adaylarının okuma motivasyonlarını etkileyen bir faktör olarak değerlendirilebilir.

\section{Türkçe Öğretmeni Adaylarının Okuma Motivasyonlarnın Evde Kitap Okuyan Birinin Olup Olmaması Değişkenine Göre İncelenmesi}

Bu bölümde; Türkçe öğretmeni adaylarının okuma motivasyonlarının evde kitap okuyan birinin olup olmaması değişkenine göre anlamlı bir şekilde farklılaşıp farklılaşmadığı araştırılmıştır. Bunun için Türkçe öğretmeni adaylarının motivasyon ölçeğine vermiş oldukları cevaplar bağımsız örneklem t- testi ile analiz edilmiştir. İlgili analizden elde edilen sonuçlar Tablo 8' de gösterilmiştir.

Tablo 8. Türkçe öğretmeni adaylarının okuma motivasyonlarıın evde kitap okuyan birinin bulunup bulunmamasına göre farklılaşıp farklılaşmadığına ilişkin analiz sonuçları

\begin{tabular}{|c|c|c|c|c|c|c|}
\hline & & $\mathbf{N}$ & $x$ & S.s & $t$ & $\mathrm{p}$ \\
\hline \multirow{2}{*}{$\begin{array}{l}\text { Benlik Alt } \\
\text { Boyutu }\end{array}$} & Var & 197 & 3,93 & ,504 & \multirow[t]{2}{*}{2,405} & \multirow[t]{2}{*}{,017 } \\
\hline & Yok & 22 & 3,66 & ,426 & & \\
\hline \multirow{2}{*}{$\begin{array}{l}\text { Yeterlilik } \\
\text { Alt Boyutu }\end{array}$} & Var & 197 & 3,57 & 629 & \multirow[t]{2}{*}{670} & \multirow[t]{2}{*}{,504 } \\
\hline & Yok & 22 & 3,47 & ,587 & & \\
\hline \multirow{2}{*}{$\begin{array}{l}\text { Tanınma } \\
\text { Alt Boyutu }\end{array}$} & Var & 197 & 3,28 & ,956 & \multirow[t]{2}{*}{$-1,617$} & \multirow[t]{2}{*}{ 107 } \\
\hline & Yok & 22 & 3,63 & ,931 & & \\
\hline \multirow{2}{*}{$\begin{array}{l}\text { Diğer Alt } \\
\text { Boyutu }\end{array}$} & Var & 197 & 3,75 & ,640 & \multirow[t]{2}{*}{2,494} & \multirow[t]{2}{*}{013} \\
\hline & Yok & 22 & 3,38 & 844 & & \\
\hline
\end{tabular}

Tablo 8 incelendiğinde; Türkçe öğretmeni adaylarının okuma motivasyonu düzeylerinin evde kitap okuyan birinin bulunup bulunmamasına göre anlamlı olarak farklılaşıp farklılaşmadığını belirlemek için yapılan bağımsız örneklemler t-testi sonucunda ortalamalar arasındaki farkın "Benlik" ( $\left.\mathrm{t}_{217}=-2,405, \mathrm{p}<.05\right)$ ve "Diğer" ( $\left.\mathrm{t}_{217}=-2,494, \mathrm{p}<.05\right)$ alt boyutlarında, evinde kitap okuyan biri bulunanlar lehine anlamlı olduğu görülmüştür. Buna göre; "Benlik" ve "Diğer" alt boyutlarında, evde kitap okuyan biri- 
nin bulunmasının, Türkçe öğretmeni adaylarının okuma motivasyonlarının yüksek olmasını etkileyen bir faktör olduğu söylenebilir. Diğer alt boyutlarda ise, evlerinde kitap okuyan biri bulunan Türkçe öğretmeni adayları ile bulunmayanlar arasındaki farkın anlamlı olmadığı görülmüştür. Buna göre evde kitap okuyan birinin bulunup bulunmamasının, "Yeterlilik" (t217=,670, p>.05) ve "Tanınma" ( $\mathrm{t}_{217}=-1,617, \mathrm{p}>.05$ ) alt boyutlarında, Türkçe öğretmeni adaylarının okuma motivasyonu düzeylerini etkileyen bir faktör olmadığı söylenebilir.

\section{Sonuç ve Tartışma}

Türkçe öğretmeni adaylarının okuma motivasyonlarını çeşitli değişkenler açısından incelemeyi amaçlayan bu çalışmadan elde edilen sonuçlar aşağıda maddeler hâlinde dikkatlere sunulmuştur.

- Çalışmada, Türkçe öğretmeni adaylarının okuma motivasyonlarının, cinsiyet faktörüne göre, sadece "Benlik" alt boyutunda kadınlar lehine anlamlı bir şekilde farklılaştığı bulunmuştur. Ölçeğin diğer alt boyutlarında ise, kadınlar ile erkeklerin ortalamaları arasındaki farkın anlamlı olmadığı tespit edilmiştir. Yani genel olarak bakıldığında cinsiyet faktörü, Türkçe öğretmeni adaylarının okuma motivasyonları üzerinde etkili bir faktör değildir. Literatür incelendiğinde; Wigfield ve Guthrie (1997), okuma motivasyonunun artırılmasinda cinsiyet faktörünün göz ardı edilmemesi gerektiğini vurgular ve kadınların erkeklerden daha olumlu okuma motivasyonu gösterdiklerini ifade eder. Benzer bir sonuca Bayram'ın (2008) gazete okurlarının okuma motivasyonları ve doyumları üzerine yapmış olduğu araştırmasında da rastlamaktayız. 925 kişinin katıldığ çalışmada araştırmacı, enformasyon, boş zaman ve eğlence alt boyutlarında, kadınların erkeklere göre daha yüksek motivasyon düzeyine sahip olduklarını tespit etmiştir. Öte taraftan, Yıldız (2013), üçüncü, dördüncü ve beşinci sınıf öğrencileri ile gerçekleştirdiği çalışmasında, kız öğrencilerin okuma motivasyonu düzeylerinin, dişsal motivasyon boyutunda, erkeklere göre daha yüksek olduğunu tespit etmiştir. Benzer sonuçları, literatürde, Katrancı (2015), Yıldız (2010), Kurnaz ve Yildız (2015) ve Bozkurt ve Memiş (2013) çalışmalarında da görmek mümkündür. 
- Çalışmada, Türkçe öğretmeni adaylarının okuma motivasyonlarının, sınıf faktörüne göre, sadece "Tanınma" alt boyutunda 2. sinıfta öğrenim görmekte olan öğretmen adayları lehine anlamlı bir şekilde farklılaştı̆̆ı bulunmuştur. Ölçeğin diğer alt boyutlarında ise, grupların ortalamaları arasındaki farkın anlamlı olmadığı tespit edilmiştir. Yani genel olarak bakıldığında öğrenim görülen sınıf faktörü, Türkçe öğretmeni adaylarının okuma motivasyonları üzerinde etkili bir faktör değildir. Bayram'ın (2008) çalışmasında da benzer bir sonuçtan bahsedilebilir. Bu çalışmada araştırmacı, "Eğlence" alt boyutunda, küçük yaş gruplarında yer alan katılımcıların okuma motivasyonlarının, büyük yaş gruplarında yer alan katılımcılara göre anlamlı şekilde arttığını tespit etmiştir. Aynı şekilde, literatürdeki Yıldız (2013), Eccles, Wigfield ve Schiefele (1998), Wigfield, Eccles ve Rodriguez (1998) ve Wigfield ve Guthire'nin (1997) çalışmalarında da sınıf düzeyi ya da yaş arttıkça okuma motivasyonunun azaldığına yönelik elde edilen sonuçlarla karşılaşmaktayız.

- Çalışmada, Türkçe öğretmeni adaylarının okuma motivasyonlarının, aile gelir düzeyi faktörüne göre, sadece "Yeterlilik" alt boyutunda aylık aile gelir düzeyi "2001-4000 TL" bandında olan öğrencilerin okuma motivasyonu düzeylerinin, "1-2000 TL" ve "6000 TL Üzeri" gelir gruplarında yer alan öğrencilere göre anlamlı düzeyde azaldığ 1 bulunmuştur. Ölçeğin diğer alt boyutlarında ise, grupların ortalamaları arasındaki farkın anlamlı olmadığı tespit edilmiştir. Bayram (2008), kendi çalışmasında, gelir düzeyi arttıkça okuyucuların gazeteyi daha çok enformasyon amaçlı, gelir düzeyi azaldıkça gazeteyi eğlence amaçlı okuduklarını tespit etmiştir. Gelir düzeyinin, okumaya yönelik olumlu tutumların ve duyguların gelişmesine yönelik etkilerini araştıran başka çalışmalara bakıldığında; Koçak $v d$. (2016), öğretmen adayları ile gerçekleştirdikleri araştırmalarında, gelir düzeyinin okuma tutumu üzerinde belirleyici bir faktör olmadığ sonucuna ulaşmışlardır. Bu gibi sonuçları, Arı ve Demir (2013), Odabaş vd. (2008), Çeçen ve Deniz (2015) ve Batur, Gülveren ve Bek (2010) araştırmalarında da görmek mümkünken, Aydın Yılmaz'ın (2006) araştırmasında ise, gelir seviyesinin düşmesinin okuma alışkanlığının da azalmasına neden olduğu tespit edilmiştir. 
- Çalışmada, Türkçe öğretmeni adaylarının okuma motivasyonlarının, evde kütüphane / kitaplık bulunup bulunmaması faktörüne göre, sadece "Benlik" alt boyutunda evinde kütüphane / kitaplık bulunan öğretmen adayları lehine anlamlı bir şekilde farklılaştığı bulunmuştur. Ölçeğin diğer alt boyutlarında ise, grupların ortalamaları arasındaki farkın anlamlı olmadığı tespit edilmiştir. Yani genel olarak bakıldığında evde kütüphane / kitaplık bulunup bulunmaması faktörü, Türkçe öğretmeni adaylarının okuma motivasyonları üzerinde etkili bir faktör değildir. Literatür incelendiğinde Türkçe öğretmeni adaylarının okuma motivasyonlarını, evde kütüphane / kitaplık bulunup bulunmaması değişkenine göre inceleyen başka çalışmalara rastlanılamamıştır. Fakat aynı düzlemde sayılabilecek araştırma sonuçlarına bakılacak olursa, Kuşdemir ve Katrancı (2016), Rüzgar (2014), Katrancı (2015), Baker (2003), Şahin (2011), Topçu (2007) ve Kurnaz ve Yıldız (2015) araştırmalarında; evde kitaplık bulunması, kendine ait bir kitaplığın olması gibi faktörlerin; bireylerde / çocuklarda okumaya yönelik olumlu tutum, eğilim ve motivasyon gelişimini de sağladığı ifade edilmiştir.

- Çalışmada, Türkçe öğretmeni adaylarının okuma motivasyonlarının, yılda okunan kitap sayısı faktörüne göre ölçeğin tüm alt boyutlarında anlamlı bir şekilde farklılaştığı görülmüştür. Buna göre; ölçeğin "Benlik", "Yeterlilik" ve "Diğer" alt boyutlarında, genel anlamda, yıl içerisinde okunan kitap sayısı arttıkça, Türkçe öğretmeni adaylarının okuma motivasyonlarının da arttığı tespit edilmiştir. Buna karşın, "Tanınma" alt boyutunda ise, okunan kitap sayısı ile okuma motivasyonu arasında ters yönde bir ilişki tespit edilmiş ve okunan kitap sayısı arttıkça, öğretmen adaylarının okuma motivasyonlarının düştüğü sonucuna ulaşılmıştır. Okunan kitap sayısı arttıkça "Tanınma" alt boyutunda, okuma motivasyonunun düşmesi; Türkçe öğretmeni adaylarının kitap okuma eylemini başkaları tarafından bilinmek, kitap kurdu olarak tanınmak, çok kitap okuduğu için etrafına hava atmak veya çevredekilerden övgü toplamak gibi faydasız amaçlar için değil; kitaptan ve kitap okumaktan gerçek manada faydalanmak, kişisel gelişimlerine katkı sağlamak, hayata yönelik farklı bakış açları kazanmak gibi faydalı amaçlar için gerçekleştirdiklerinin 
bir işareti olarak görülebilir. Yani bu durum, okunan kitap sayısı arttıkça, bilinçli okuma da artmaktadır şeklinde yorumlanabilir. Başka bir ifadeyle okunan kitap sayısının artması, okumaya yönelik olumlu ve faydalı motivasyon oluşturma bağlamında kritik öneme sahiptir. Yukarıdaki sonuçlar, yıl içerisinde okunan kitap sayısının, Türkçe öğretmeni adaylarının okuma motivasyonu düzeylerini belirleyen önemli bir faktör olduğunu göstermektedir. Literatür incelendiğinde benzer şekilde, Kurnaz ve Yıldız (2015) ve Öztürk ve İleri Aydemir (2013) de okunan kitap sayısının veya okumaya ayrılan sürenin artmasının, okuma motivasyonunu da artıcağını ifade etmişlerdir. Literatürde yer alan, Durualp, Durualp ve Çiçekoğlu (2013), Karim ve Hasan (2007), Bağcı 2010, Balcı vd. (2012), Stokmans (1999), Schooten ve Glopper (2002), Özbay vd. (2008), Doğan Yılmaz 2010 ve Yıldız ve Keskin (2016) gibi araştırmalarda ise, okunan kitap sayısı değişkeninin okumaya yönelik olumlu tutum oluşturma bağlamında önemli bir faktör olduğu ifade edilmiştir.

- Çalışmada, Türkçe öğretmeni adaylarının okuma motivasyonlarının, evde kitap okuyan birinin bulunup bulunmamasına göre, "Benlik" ve "Diğer" alt boyutlarında evlerinde kitap okuyan biri bulunan öğretmen adayları lehine anlamlı bir şekilde farklılaştığı bulunmuştur. Ölçeğin diğer alt boyutlarında ise, grupların ortalamaları arasındaki farkın anlamlı olmadığı tespit edilmiştir. Okumaya yönelik olumlu tutum ve davranışların küçük yaşlarda kazanılmasının daha kolay olduğu düşünülünce, evinde kitap okuyan birileri olan bireylerin çocuk yaşlardan itibaren olumlu okuma ortamı içerisinde bulunacakları ve bu durumun da onlarda okumaya yönelik olumlu tutum oluşturma ve okumaya yönelik motivasyonlarını yükseltme bağlamında fayda sağlayacağı aşikârdır. Yani küçük yaşlarda, okuma konusunda, kendilerine olumlu bir rol model bulabilen çocuklar; okumaya yönelik olumlu davranış ve düşünce geliştirme noktasında da avantajlı olacaklardır. Bu nedenle ebeveynlerin, birçok konuda olduğu gibi okuma konusunda da ideal bir model olma sorumlulukları vardır. Çünkü ebeveynleri kitap okuyan çocuklar, hayatlarının geri kalan kısımlarında, okumaya karşı daha istekli ve meraklı olacaklardır (Baran, 2011; Tezel, 2009; Çakmak ve Yılmaz, 2009; Strommen 
ve Mates, 2004; Yılmaz, 2009 ve Neuman, 1986). Literatürde, yukarıdaki ifadeleri destekleyen araştırma sonuçlarına rastlamak mümkündür. Örneğin; Y1ldız ve Keskin (2016), Durualp, Durual ve Çiçekoğlu (2013), Kurnaz ve Yıldız (2015) ve Öztürk ve İleri Aydemir (2013) gibi çalışmalarda; evinde kitap okuyan birileri olan çocukların, olmayan çocuklara göre daha yüksek bir okuma tutumuna ve motivasyonuna sahip oldukları vurgulanmıştır.

Türkçe öğretmeni adaylarının okuma motivasyonlarını çeşitli değişkenler açısından incelemeyi amaçlayan bu çalışmadan elde edilen sonuçlar doğrultusunda, aşağıdaki önerilere yer verilmiştir:

- Araştırmada, alt sınıflarda öğrenim görmekte olan Türkçe öğretmeni adaylarının okuma motivasyonlarının, üst sınıflarda öğrenim görmekte olanlara göre daha yüksek olduğu görülmüsştür. Üst sınıflarda yaşanan mezun olma, sınav kaygısı, iş bulma gibi durumların vermiş olduğu kaygı ve endişeler; öğretmen adaylarının bu motivasyon kayıplarının sebebi olarak gösterilebilir. Bu nedenle, böylesine kaygıların ve endişelerin azaltılmasına yönelik profesyonel rehberlik hizmetlerinin üniversitelerde sunulması önem arz etmektedir. Bu bağlamda üniversitelerde, etkin çalışabilen ve öğrencilerini yönlendirebilen rehberlik servislerine ihtiyaç vardır. Hâlihazırda var olan bu tür servislerin ise, kendilerini güncellemeleri ve daha aktif bir çalışma profiline bürünmeleri elzemdir.

- Türkçe öğretmeni adaylarının kitapla iç içe bir yaşam sürmeleri gerekirken, araştırmaya katılan öğretmen adaylarının \%70'ten fazlasının, bir yılda 10 'dan daha az sayıda kitap okudukları tespit edilmiştir. Bu durum, öğretmen adaylarının okuma motivasyonlarının düşmesine neden olurken başka önemli problemleri de beraberinde getirmektedir. En başta da, okumaktan uzak ve okumayı sevmeyen kişilerin okullarda öğretmen olarak görev alması probleminden bahsedilebilir. Okumayan bir öğretmenin okuyan bir nesil yetiştirmesini beklemek yersizdir. Bu nedenle, tüm eğitim kademelerinde olduğu gibi yükseköğretimde de, özellikle eğitim fakültelerinde, öğrencilerin daha fazla kitap okumalarını sağlayacak etkinlikler planlanmalı ve bu doğrultuda faydalı olabilecek tüm düzenlemeler gerçekleştirilmelidir. 
Tüm öğretmen adaylarının, özellikle de Türkçe öğretmeni adaylarının, mesleğe başlamadan önce iyi birer okur olmaları gerekmektedir ki; burada eğitim fakültelerine önemli görevler düşmektedir.

- Düşük gelir seviyesi, her kesimden insanda olduğu gibi Türkçe öğretmeni adaylarında da okuma motivasyonunu etkileyen bir faktördür. Öğretmen adaylarının ekonomik sebeplerden dolayı kitaptan ve okumaktan uzak kalmasını engellemek adına üniversite ve fakülte kütüphaneleri büyük önem arz etmektedir. Buraların kitap bakımından zengin bir donanıma sahip olması gerekmektedir. Ayrıca yeni çıan eserler takip ve tespit edilmeli; bu eserler, belirli aralıklarla bu kütüphanelerin raflarına eklenmelidir.

- Okuma alışkanlığının ve okumaya yönelik olumlu duyguların küçük yaşlardan itibaren kazanıldığı gerçeğinden hareketle, başta Türkçe öğretmeni adayları olmak üzere, tüm öğretmen adayları bu bağlamda eğitilmeli ve bilinçlendirilmelidir.

- Türkçe öğretmenliği bölümündeki okuma ile ilgili dersler, öğrencilerde okumaya yönelik istek ve merak uyandıracak biçimde planlanmalı ve yürütülmelidir. Bu derslerde okumaya yönelik kuramsal bilgilerin aktarımı kadar öğrencilerde okuma sevgisi oluşturma amacı da güdülmelidir.

- Üniversitelerde, okumaya ve kitaba yönelik çeşitli seminerler, konferanslar, imza günleri, sergiler, yazarlarla buluşma etkinlikleri, çeşitli yayınevleri ile öğrencilerin buluşmasını sağlama, kitap değişim günleri, kitap hediye etme günleri gibi farklı etkinlikler yapılmalıdır.

- Diğer bölümlerde öğrenim görmekte olan öğretmen adaylarının da okumaya yönelik motivasyonları incelenmeli ve motivasyonlarını düşüren ya da artıran faktörlerin neler olduğu tespit edilmelidir.

- Literatür incelendiğinde Türkçe öğretmeni adaylarının okuma motivasyonları çeşitli değişkenler açısından inceleyen başka araştırmalara rastlanılamamıştır. Bu nedenle bu çalışmaya benzer çalışmaların farklı örneklem grupları ile gerçekleştirilerek, sonuçların karşılaştırılması ve daha genellenebilir sonuçlara ulaşılması önemli görülmektedir.

- Farklı örneklem gruplarından toplanan veriler ile gerçekleştirilecek çalışmalar da, elde edilen sonuçların etki büyüklüğü ve genellenebilirliği anlamında önemli görülmektedir. 


\title{
EXTENDED ABSTRACT
}

\section{Examination of The Reading Motivations of Turkish Teacher Candidates in Terms of Various Variables}

\author{
* \\ Nurullah Şahin \\ A ̆gr İbrahim Çeçen University
}

The act of reading, which requires active use of many sensory organs and mental processes, also constitutes one of the most effective learning ways. Since reading is an important part of understanding and all courses require reading, it is not difficult to estimate that a student whose reading skill has not developed will not be successful. When the literature is examined, it is seen that there are many important factors affecting reading success; these are reading attitude and reading motivation. Reading motivation can be expressed as the personal goals, values and beliefs that affect reading processes, results and subjects.

This study aims to examine the reading motivations of Turkish teacher candidates in terms of various variables. The study, in which a quantitative research approach was adopted, was conducted with the screening model. The study group consists of 219 students studying at the Turkish Education Department of the Faculty of Education of Ağri İbrahim Çeçen University in the fall semester of the 2018-2019 academic year. "The Adult Reading Motivation Scale," developed by Schutte and Malouff (2007) and translated into Turkish by Ylddiz et al. (2013), was used in the study as the data collection tool. As all data obtained from the study were distributed normally, parametric tests were used in data analysis.

Independent $\mathrm{t}$-test analysis was used to examine whether the reading motivations of the Turkish teacher candidates differed significantly according to "gender", "whether there was a library / bookcase at home" along with "whether there was someone reading book at home", and one-factor analysis of variance was used to examine whether this motivation differed significantly according to the variants of "grade", "family's income level" 
and "the number of books read per year". The LSD test was used to determine which group the significant difference was in favor of as a result of the one-factor analysis of variance. In the study where the results obtained were shown with tables in accordance with the sub-objectives of the study, the significance of the data was tested at $\mathrm{p}<.05$ level.

- The gender factor has a determining role in the reading motivations of the Turkish teacher candidates in favor of women under the subdimension "Self." However, it can be said that the gender factor does not affect the reading motivation level of the Turkish teachers under the sub-dimensions "Competence," "Recognition," and "Other" on the scale.

- The results obtained has revealed that, under the sub-dimension "Recognition" on the scale, the reading motivation of the teacher candidates at the 2nd grade was significantly higher than those studying at other grades. However, it is seen that the difference between the averages of the groups under the other sub-dimensions "Self," "Competence," and "Other" is not significant. Accordingly, it can be said that the grade level of education has no significant effect on the reading motivation of the Turkish teacher candidates in the sub-dimensions of "Self," "Competence," and "Other."

- According to the results obtained, it has been found that under the sub-dimension "Competency," the reading motivation of the students whose family's monthly income level was "2001-4000 Turkish Liras" was significantly less than those whose family's monthly income was "1-2000 Turkish Liras" and "6000+ Turkish Liras". Accordingly, the monthly income level of the family can be evaluated as a factor affecting the reading motivation of the Turkish teacher candidates under the sub-dimension "Competence." It is seen that the difference between the average of the groups is not significant under the sub-dimensions "Self," "Recognition," and "Other" on the scale. Accordingly, it can be said that the family's monthly income level has no significant effect on the reading motivation of the Turkish teacher candidates in the sub-dimensions of "Self," "Recognition," and "Other."

- According to the results, it was found that, only under the sub-dimension "Self" on the scale, there was a significant difference in favor of the students who had a library/bookcase at home. Accordingly, it can 
be said that the reading motivation of the Turkish teacher candidates who had a library / bookcase at home was higher than those who had not under the sub-dimension "Self." Under the other sub-dimensions, it has been seen that there was no significant difference between the Turkish teacher candidates who had a library / bookcase at home and those who had not. It can be said that whether there is a library/bookcase at home does not affect the reading motivation level of the Turkish teachers under the sub-dimensions "Competence," "Recognition," and "Other".

- The study has revealed that the reading motivation of the Turkish teacher candidates differed significantly according to the number of books read per year under all sub-dimensions on the scale. Accordingly, it was determined that the reading motivation of the Turkish teacher candidates increased as the number of books read per year increased under the sub-dimensions "Self" "Competence" and "Other." On the other hand, under the sub-dimension "Recognition," an inverse relationship was found between the number of books read and the reading motivation, which led to the conclusion that as the number of books increased, the reading motivation of the teacher candidates decreased. These results show that the number of books read per year is an important factor determining the reading motivation level of the Turkish teacher candidates.

- Under the other sub-dimensions "Self" and "Other" on the scale, it has been seen that the reading motivation of the Turkish teacher candidates increased according to whether there was someone reading a book at home. Accordingly, it can be said that whether there is someone reading a book at home is a factor increasing the reading motivation of the Turkish teacher candidates under the sub-dimensions "Self" and "Other." Under the other sub-dimensions, it has been seen that there was no significant difference between the Turkish teacher candidates who had a family member reading book at home and those who had not. It can be said that whether there is someone reading a book at home does not affect the reading motivation level of the Turkish teachers under the sub-dimensions "Competence" and "Recognition." 


\section{Kaynakça / References}

Akyol, H. (2005). Türkçe ilk okuma yazma öğretimi. Ankara: Pegem A Yayıncllık. Arı, E. ve Demir, M. K. (2013). İlköğretim bölümü öğretmen adaylarının kitap okuma, alışkanlıklarının değerlendirilmesi. Ana Dili Ĕ̆itimi Dergisi, 1(1), 116-128.

Aydın Yılmaz, Z. (2006). Sınıf öğretmeni adaylarının okuma alışkanlığı. Illköğretim Online, 5(1), 1-6.

Bağc1, H. (2010). İlköğretim II. kademe öğrencilerinin okumaya yönelik tutumlarının değerlendirilmesi. II. Uluslararası Dünya Dili Türkçe Sempozyumu Bildirileri, 9-11 Aralık 2009, Lefkoşa: Uluslararası Kıbrıs Üniversitesi.

Baker, L. (2003). The role of parents in motivating struggling readers. Reading $\mathcal{E}$ Writing Quarterly: Overcoming Learning Difficulties, 19(1), 87-106.

Baker, T. ve Wigfield, A. (1999). Dimensions of children's motivation for reading and their relations to reading activity and reading achievement. Reading Research Quarterly, 34, 2- 29.

Balcı, A.; Uyar, Y. vd. (2012). İlköğretim 6. sınıf öğrencilerinin okuma alışkanlıkları, kütüphane kullanma sıklıkları ve okumaya yönelik tutumlarınin incelenmesi. Turkish Studies. 7(4), 965-985.

Baran, G. (2011). Çocuk gelişimine giriş. (Ed: N. Aral ve G. Baran), Çocuk gelişimi. içinde (s.17-51), İstanbul: Ya-Pa Yayın A.Ş.

Batur, Z., Gülveren, H. ve Bek, H. (2010). Öğretmen adaylarının okuma alışkanlıkları üzerine bir araştırma: Uşak Eğitim Fakültesi örneği. Uşak Üniversitesi Sosyal Bilimler Dergisi, 3(1), 32-49.

Bayram, F. (2008). Gazete okurlarının okuma motivasyonları ve doyumları üzerine bir kullanımlar ve doyumlar araştırması. Anadolu Üniversitesi Sosyal Bilimler Dergisi, 8(1), 321-336.

Biçer, N. ve Alan, Y. (2017). Türkçe öğretmeni adaylarının kitap okuma alışkanlıklarının genel öz yeterlikleri üzerindeki etkisi. Erzincan Üniversitesi Ĕ̆itim Fakültesi Dergisi, 19(1), 100-116.

Bozkurt, M. ve Memiş, A.(2013). Beşinci sınıf öğrencilerinin üstbilişsel okuduğunu anlama farkındalığı ve okuma motivasyonları ile okuma düzeyleri arasındaki ilişki. Ahi Evran Üniversitesi Kırşehir Eğitim Fakültesi Dergisi, 14(3), 47-160.

Carnine, D. W., Silbert, J., Kame'enui E. J., Tarver, S. G. ve Jungjohann K. (2006). Teaching struggling and at-risk readers a direct instruction approach. New Jersey: Pearson Education. 
Çakmak, T. ve Yılmaz, B. (2009). Okul öncesi dönem çocuklarının okuma alışkanlığına hazırlık durumları üzerine bir araştırma: Hacettepe Üniversitesi Beytepe Anaokulu örneği. Türk Kütüphaneciliği, 23(3), 489-509.

Çeçen, M. A. ve Deniz, E. (2015). Lise öğrencilerinin okumaya yönelik tutumları:Diyarbakır ili örneği. Mustafa Kemal Üniversitesi Sosyal Bilimler Enstitüsü Dergisi, 12(30), 193-212.

Doğan Yılmaz, E. (2010). Hemşirelik öğrencilerinin eleştirel düşünme düzeyleri ve kitap okuma alışkanlığına ilişkin tutumları. Yayınlanmamış Yüksek Lisans Tezi. Hacettepe Üniversitesi, Ankara.

Durualp, E.; Çiçekoğlu, P. ve Durualp, E. (2013). 6-8. sınıftaki öğrencilerin okumaya ilişkin tutumlarının internet ve kitap okuma alışkanlıkları açısından incelenmesi. Uluslararası Türkçe Edebiyat Kültür Ĕ̆itim Dergisi. 2(1), 115-132.

Eccles, J. S.; Wigfield, A. ve Schiefele, U. (1998). Motivation to succeed. In N. Eisenberg (Ed.), Handbook of child psychology (Vol. IV, 5th ed., p. 10171095). New York: John Wiley.

George, D. ve Mallery, M. (2010). SPSS for windows step by step: a simple guide and reference, 17.0 update (10a ed.) Boston: Pearson.

Guthrie, J. T. ve Wigfield, A. (2000). Engagement and motivation in reading. In M. L. Kamil, P. B. Mosenthal, P. D. Pearson, ve R. Barr (Eds.), Handbook of reading research (3rd ed., p. 403 - 422). New York: Longman.

Güneş, F. (2007). Türkçe öğretimi ve zihinsel yapılandırma. Ankara: Nobel Yayın Dağıtım.

Hair, J. F.; Black, W. C.; Babin, B. J.; Anderson, R. E. ve Tatham, R. L. (2013). Multivariate Data Analysis. Pearson Education Limited.

Karasar, N. (2008). Bilimsel araştırma yöntemi. Ankara: Nobel Yayıncılık.

Karim, N. S. A. ve Hasan, A. (2007). Reading habits and attitude in the digital age: Analysis of gender and academic program differences in Malaysia. The Electronic Library, 25(3), 285-298.

Katrancı, M. (2015). İlkokul dördüncü sınıf öğrencilerinin kitap okuma motivasyonlarının incelenmesi. Ana Dili Ĕ̆itimi Dergisi, 3(2), 49-62.

Koçak, B., Çermik, F., Polat, S. ve Şahin, N. (2016). Öğretmen adaylarının kitap okuma tutumlarının çeşitli değişkenler açısından incelenmesi. Uluslararası Türkçe Edebiyat Kültür Ĕ̆itim Dergisi, 5(1), 395-411.

Korkut, K. ve Babaoğlan, E. (2012). Sınıf öğretmenlerinin öz yeterlik inançları. Uluslar Arası Yönetim İktisat ve İşletme Dergisi, 8(16), 269-281. 
Kurnaz, H. ve Yıldız, N. (2015). Ortaokul öğrencilerinin okuma motivasyonlarının çeşitli değişkenlere göre değerlendirilmesi. Türkiye Sosyal Araştırmalar (TSA) Dergisi. 19(3), 53-70.

Kurudayığlu, M. ve Çelik, G. (2013). Türkçe öğretmeni adaylarının okumaya ve okuma eğitimine ilişkin özyeterlik algıları. Uşak Üniversitesi Sosyal Bilimler Dergisi, 6(4), 109- 138.

Kuşdemir, Y. ve Katranc1, M. (2016). Okumada Kaygı ve Anlama: Ana Fikri Bulamıyorum Öğretmenim! Eğitim ve Bilim, 41(183), 251-266.

MEB. (1995). İlköğretim programı. Ankara: MEB Yayınları.

Neuman, S. (1986).The home environment and fifth-gradestudents' leisure reading. Elementary School Journal, 83, 131-137.

Odabaş, H.; Odabaş, Z. Y. ve Polat, C. (2008). Üniversite öğrencilerinin okuma alışkanlığı: Ankara Üniversitesi örneği. Bilgi Dünyası, 9(2), 431-465.

Özbay, M., Bağcl, H. ve Uyar, Y. (2008). Türkçe öğretmeni adaylarının okuma alışkanlığına yönelik tutumlarının çeşitli değişkenlere göre değerlendirilmesi. İnönü Üniversitesi Eğitim Fakültesi Dergisi, 9(15), 117-136.

Öztürk, E. ve İleri-Aydemir, Z. (2013). Başlangıç düzeyi okuyucularının okuma motivasyonlarının, günlük kitap okuma süreleri ve ailenin okuma durumuna göre değerlendirilmesi. Kastamonu Eğitim Dergisi, 21(3), 1105-1116.

Paris, S. G.; Wasik, B. A. ve Turner, J. C. (1991). The development of strategic readers. In R. Barr, M. I. Kamil, P. Mosenthal, and P. D. Pearson (Eds.), Handbook of reading research $(2,609-640)$. New York: Longman.

Pintrich, P. ve Schunk, D. (1996). Motivation in education: theory, research \& applications. Ch. 3. Englewood Cliffs, NJ: Prentice-Hall.

Rüzgar, M. E. (2014). Beşinci sını öğrencilerinin okuduğunu anlama düzeylerinin öğrenme stilleri bağlamında incelenmesi. Yayımlanmamış Yüksek Lisans Tezi. Ankara Üniversitesi Eğitim Bilimleri Enstitüsü, Ankara.

Sanc1, D. (2002). İlköğretim 6. sını öğrencilerinin toplumsal, ekonomik ve kültürel durumlarının okuma motivasyonlarına etkisi. Yayınlanmamış Yüksek Lisans Tezi, Atatürk Üniversitesi, Sosyal Bilimler Enstitüsü, Erzurum.

Schooten, E. ve Glopper, K. (2002). The relation between attitude toward reading adolescent literature and literary reading behavior. Poetics. 30 , 169-194.

Schutte, N. S. and Malouff, J. M. (2007). Dimensions of reading motivation: Development of an adult reading motivation scale. Reading Psychology: An International Quarterly, 28, 469 - 489. 
Stokmans, M. J. W. (1999). Reading attitude and its effect on leisure time reading. Poetics. 26, 245-261.

Strommen, L. T. ve Mates, B. F. (2004). Learning tolovereading: Interview swith older children and teens. Journal of Adolescent ve Adult Literacy, 48, 188-199.

Şahin, N. (2011). Ilköğretim ikinci kademe öğrencilerinin yabancı dildeki okuma kaygılarının kaynakları ve bu kaygılarla duygusal başa çıkma stratejileri: Bir durum incelemesi. Yayımlanmamış Yüksek Lisans Tezi. Gazi Üniversitesi Eğitim Bilimleri Enstitüsü, Ankara.

Şahin, N. (2012). Maniheist ve Budist Uygur şiirinin dilin dört temel becerisi açısından incelenmesi. Yayınlanmamış Yüksek Lisans Tezi, Atatürk Üniversitesi Eğitim Bilimleri Enstitüsü, Erzurum.

Tabachnick, B. G. ve Fidell, L. S. (2013). Using Multivariate Statistics (sixth ed.). Boston: Pearson.

TDK. (2009). Türkçe sözlük. Ankara: Türk Dil Kurumu Yayınları.

Tezel, D. (2009). Bir aile olmak. Erken çocukluk gelişimi ve eğitimi. (Ed: Y. Fazlıoğlu), 173-183, İstanbul: Kriter Yayınlar.

Topçu, Y. E. (2007). İlköğretim 6,7 ve 8. sınıf öğrencilerinin okuma alışkanlıkları. Milli Ĕ̆gitim Dergisi. 176, 36-57.

Turner, J. C. (1995). The influence of classroom contexts on young children's motivation for literacy. Reading Research Quarterly, 30, 410-441.

Ülper, H. ve Bağcl, H. (2012). Türkçe öğretmeni adaylarının öğretmenlik mesleğine dönük öz yeterlik algıları. International Periodical For The Languages, Literature and History of Turkish or Turkic, 7(2), 1115-1131.

Ünalan, Ş. (2001). Türkçe öğretimi. Ankara: Nobel Yayın Dağıtım.

Ürün Karahan, B. (2018). Türkçe öğretmenliği ve Türk dili ve edebiyatı bölümü öğrencilerinin yaşam boyu öğrenme eğilimlerinin okumaya yönelik motivasyonlarıyla ilişkisi. International Journal of Language Academy, 6(1), 112-119.

Wigfield, A. ve Guthrie, J. T. (1997). Relations of children's motivation for reading to the amount and breadth of their reading. Journal of Educational Psychology, 89, 420-432.

Wigfield, A., Eccles, J. S. ve Rodriguez, D. (1998). The development of children's motivation in school contexts. In. A. Iran-Nejad and P. D. Pearson (Eds.), Review of research in education (Vol. 23, s.73-118). Washington, DC: American Educational Research Association. 
Wigfield, A.; Guthire, J. T.; Tonks, S. ve Prencevich, K. C. (2004). Children's motivation for reading domain specificity and instructional influences. The Journal of Educational Research, 97, 299-309.

Yıldız, M. (2010). Ilköğretim 5. sinıföğrencilerinin okuduğunu anlama, okuma motivasyonu ve okuma alışkanlıkları arasındaki ilişki. Yayımlanmamış Doktora Tezi. Gazi Üniversitesi, Eğitim Bilimleri Enstitüsü, Ankara.

Yıldız, M. (2010). İlköğretim 5. sinıföğrencilerinin okuduğunu anlama, okuma motivasyonu ve okuma alı̧̧kanlığı arasındaki ilişki. Yayımlanmamış Doktora Tezi, Gazi Üniversitesi, Ankara.

Yıldız, M. (2013). İlköğretim 3, 4 ve 5. sınıf öğrencilerinin okuma motivasyonlarının incelenmesi. Eğitim ve Bilim, 38(168), 260-271.

Yıldız, M.; Yıldırım, K.; Ateş, S. ve Çetinkaya, Ç. (2013). Yetişkin okuma motivasyonu ölçeğinin Türkçe uyarlaması. Elektronik Sosyal Bilimler Dergisi, 12(44), 348-359.

Yıldız, N. ve Keskin, H. (2016). Ergenlik dönemindeki öğrencilerin dijital ve matbu okumaya karşı tutumlarının çeşitli değişkenlere göre değerlendirilmesi. Mersin Üniversitesi Ĕ̆gitim Fakültesi Dergisi, 12(1), 344-361.

Yılmaz, B. (2009). Çocuklarda okuma kültürünü geliştirmede ebeveyn ve öğretmenin rolü. Çocuk ve Okuma Kültürü Sempozyumu Kitabı. (Ed: A. Afacan), içinde (s.133-140), Ankara: Eğitim Sen Yayınları.

\section{Kaynakça Bilgisi / Citation Information}

Şahin, N. (2019). Türkçe öğretmeni adaylarının okuma motivasyonlarının çeşitli değişkenler açısından incelenmesi. OPUS-Uluslararası Toplum Araştırmaları Dergisi, 13(19), 393-423. DOI: 10.26466 /opus.588759. 